\title{
Irena Szczepankowska, Studia nad polszczyznq epoki stanisławowskiej, Białystok 2004, s. 221
}

Książka I. Szczepankowskiej prezentuje nowe i ciekawe spojrzenie na polszczyznę końca wieku osiemnastego, wieku nader interesującego z tego powodu, iż był to okres „przełamywania się dwu epok: średniopolskiej (z centrum języka literackiego w Krakowie) i nowopolskiej (z centrum języka literackiego w Warszawie), okres w którym wyraźnie rysuje się obumieranie starego i wzrost nowego porządku"1. Autorka skupia swoją uwagę przede wszystkim na stanie polszczyzny i świadomości językowej Polaków w dobie panowania Stanisława Augusta Poniatowskiego, a więc w czasie gwałtownego renesansu politycznego i kulturalnego ${ }^{2}$.

Praca I. Szczepankowskiej jest tym cenniejsza, iż dotyczy epoki $\mathrm{w}$ dziejach języka polskiego od wielu lat nie badanej. I chociaż mogłoby się wydawać, że ówczesny język został już opracowany przez wielu specjalistów, niniejsza publikacja udowadnia, że wciąż istnieją nie opisane obszary naszej wiedzy o osiemnastowiecznej polszczyźnie, którym warto poświęcić więcej miejsca, a tym samym uzupełnić naszą znajomość dziejów rozwoju języka polskiego. Po recenzowaną książkę warto sięgnąć też i z tego powodu, iż I. Szczepankowska w swoim zbiorze studiów podejmuje zróżnicowaną problematykę oraz metody opisu. Wynika to - jak sama Autorka stwierdza w Słowie wstępnym - „ze świadomego dążenia do ukazania spektrum zagadnień wartych dalszego zgłębiania zarówno w planie synchronicznym (z uwzględnieniem innych odmian wypowiedzi i szerszego materiału porównawcze-

\footnotetext{
1 I. Bajerowa, Ksztattowvanie się systemu polskiego języka literackiego w XVIII wieku, Wrocław-Warszawa-Kraków 1964, s. 232-233.

2 Tamże, s. 5.
} 
go), jak i diachronicznym (podjęte problemy wymagają prześledzenia na materiale wcześniejszych i późniejszych okresów historycznych). Zasadne wydaje się także zastosowanie różnorodnych «ścieżek» interpretacyjnych w opisie zagadnień funkcjonowania języka: analizy pragmatycznej, uwzględniającej szerszy kontekst pozalingwistyczny badanych zjawisk, lub metod strukturalistycznych i generatywnych - do przedstawienia problemów gramatycznych".

Interesująca nas książka składa się z dwóch części. W pierwszej zatytułowanej $Z$ problematyki języka prawnego zostały zamieszczone teksty dotyczące języka prawnego epoki. Temu zagadnieniu I. Szczepankowska poświęciła osobną monografię Język prawny I Rzeczypospolitej $w$ "Zbiorze praw sądowych" Andrzeja Zamoyskiego (w druku), w której szczegółowo charakteryzuje język kodeksu. Druga część: $Z$ badań nad odmianami języka i wypowiedzi związana jest z różnymi aspektami funkcjonowania polszczyzny epoki stanisławowskiej. W tym względzie Autorkę interesują głównie odmiany wypowiedzi nieartystycznych, użytkowych.

Pierwsze i najobszerniejsze opracowanie Kultura jezzyka prawnego w XVIII wieku - przyczynek do ewolucji zasad techniki ustawodawczej (od oświecenia po czasy współczesne) składa się z piętnastu rozdziałów, które traktują o rozwoju językowej techniki prawodawczej od oświecenia po czasy współczesne. Autorka swoje rozważania opiera na Zbiorze praw sqadowych Andrzeja Zamoyskiego. Punkt odniesienia dla scharakteryzowania ewolucji poglądów prawniczych stanowią komentarze dziewiętnastowiecznego prawnika, teoretyka prawa i dydaktyka - Walentego Dutkiewicza. Ponadto I. Szczepankowska uwzględnia współczesne zalecenia normatywne, zawarte w Zasadach techniki prawodawczej oraz w pracach współczesnych teoretyków i praktyków w dziedzinie prawa.

Pierwszy rozdział wyżej wymienionego studium poświęcony jest rozwojowi języka prawnego $z$ punktu widzenia obecności $w$ nim zapożyczeń terminologicznych i makaronizmów. I. Szczepankowska nie poprzestaje tu tylko na opisie wyrazów zapożyczonych, głównie łacińskich i makaronizmów składniowo-frazeologicznych, ale przede wszystkim poszukuje przyczyn ich występowania. Ponadto Autorka zauważa, że problem przyswajania obcej leksyki z dziedziny prawa 
nie jest obcy również współczesnym legislatorom: „w dobie internacjonalizacji prawa, a zwłaszcza włączenia się III Rzeczypospolitej w budowanie zjednoczonej Europy, odżywa problem językowego przyswajania aktów prawodawczych wspólnoty europejskiej, a co za tym idzie - tłumaczenia lub też polszczenia stale wzbogacanej leksyki z dziedziny prawa" (s. 21).

Drugi rozdział dotyczy trudności, z jakimi borykali się ustawodawcy i interpretatorzy prawa $w$ związku $z$ przenoszeniem instytucji i pojęć prawa rzymskiego i kanonicznego na grunt polski. Owe problemy, stwierdza Autorka, związane z różnego rodzaju modyfikacjami znaczeń (często prowadzącymi do wieloznaczności) nazw przejętych z prawa rzymskiego, uwarunkowane były historycznie i społecznie. Chodzi tu o dostosowywanie prawa rzymskiego przez prawodawstwa europejskie najpierw do średniowiecznych instytucji feudalnych, następnie - do nowych stosunków kapitalistycznych.

Rozdział Synonimy rodzime i odpowiedniki nazwowe z różnych genetycznie kodów językowych jest udaną próbą obiektywnej oceny funkcjonowania w osiemnastowiecznym języku prawnym nazw wspólnofunkcyjnych. Autorka wskazuje zagrożenia wynikające $\mathrm{z}$ istnienia "copia verborum”, czyli „niepotrzebnej rozmaitości słów”, a także podaje przyczyny istnienia polileksji w osiemnastowiecznym zbiorze praw.

Kolejne rozdziały poświęcone są: dubletom słowotwórczym, których istnienie wynika $\mathrm{z}$ braku wyraźnej specjalizacji znaczeniowej formacji współrdzennych i prowadzi do niepotrzebnego nadmiaru nazw; neologizmom i neosemantyzmom (tu I. Szczepankowska rozważa zasadność wprowadzania ich do osiemnastowiecznego języka prawnego, a także poszukuje wytłumaczenia takich działań); wysoce niepożądanej $\mathrm{w}$ prawodawstwie wieloznaczności; precyzji znaczeniowej - zasadzie, przeciwko której wykraczają nie tylko zjawiska synonimii i wieloznaczności, ale także niedostateczne uwzględnianie różnic znaczeniowych między terminami oraz niedobór pewnych określeń, wprowadzających szczegółowe dystynkcje między pojęciami; sprzeczności i tautologii; skrótom myślowym a niejasności wypowiedzi. Wśród zagadnień związanych $\mathrm{z}$ zasadami techniki ustawodawczej znalazły się także kwestie dotyczące składni i interpunkcji wypowiedzi prawnej, neutralności słownictwa, języka prawnego 
a języka prawniczego, języka prawnego a języka potocznego, etykiety językowej oraz perswazji i innych aktów mowy w tekście ustawodawczym.

Uwagę czytelnika zwraca niezwykle zajmujący artykuł Występne akty mowy w świetle norm prawa polskiego epoki stanisławowskiej, w którym I. Szczepankowska dokonuje analizy nazw odnoszących się do zakazanych przez ówczesne prawo, a więc występnych aktów mowy. Materiału źródłowego dostarcza Autorce wspomniany już wyżej Zbiór praw sq̨dowych Andrzeja Zamoyskiego, w którym „występne akty mowy - pisze Autorka - nie są realizowane, lecz są przez ustawodawcę jedynie charakteryzowane jako zachowania językowe, sprzeczne $z$ prawem i przez to będące przedmiotem zakazów sformułowanych $\mathrm{w}$ poszczególnych przepisach, przewidujących sankcje za krzywoprzysięstwo, obrazę majestatu, fałszywe zeznania itp." (s. 81). W omawianym artykule zostały scharakteryzowane illokucyjnie akty zwane pogróżką, obrazą/zniewagą, potwarzą, paszkwilem, krzywoprzysięstwem, fałszywym zeznaniem, fałszywym doniesieniem, namową (do występku), obrazą, zmową/spiskiem/układem, wyzwaniem na pojedynek.

Studium pt. Definicje prawodawcze w kodeksie Andrzeja Zamoyskiego - struktura wypowiedzi i znaczenie wyrażeń predykatywnych nawiązuje do badań autorki nad językiem prawnym I Rzeczypospolitej. Materiał źródłowy został zaczerpnięty ze Zbioru Praw Sądowych Andrzeja Zamoyskiego. I. Szczepankowska wyodrębnia i klasyfikuje tu wypowiedzi, które są przykładami norm ustalających znaczenia pojęć prawnych. Omawiany artykuł jest jak gdyby uzupełnieniem badań Autorki, których wyniki zostały zawarte w pracy Język prawny... i dotyczyły wypowiedzi, będących sformułowaniem określonej dyrektywy, czyli nakazu, zakazu lub pozwolenia skierowanego przez prawodawcę $\mathrm{N}$ do adresata Y. W niniejszym opracowaniu Autorka analizuje 34 typy wypowiedzi z uwzględnieniem modeli struktur predykatywno-argumentowych oraz zróżnicowania leksykalnego wykładników aktu definicyjnego i łączliwości składniowej predykatów. Ponadto I. Szczepankowska zwraca uwagę na to, iż w osobnym opracowaniu warto byłoby prześledzić ewolucję tego gatunku wypowiedzi prawodawczej. 
Dopełnienie badań Autorki na temat funkcji semantycznej i tekstotwórczej nazw podstawowych pojęć prawnych, wokół których zorganizowany jest cały system pojęciowy ${ }^{3}$ stanowi ostatnie opracowanie pierwszej części recenzowanej książki. I. Szczepankowska analizuje tu wyrażenia należące do ważnych $\mathrm{w}$ systemie jurydycznym pól pojęciowych, czyli takich, jak: 'prawo', 'sąd', 'sprawa'. Są to wyrażenia stwierdza Autorka - „porządkujące sferę komplikujących się instytucji i norm poprzez rozbudowanie płaszczyzny hiponimii $\mathrm{w}$ polu pojęciowym, wyznaczonym przez hiperonim" (s. 96). Nazwy takie mają charakter głównie skupień terminologicznych. Odzwierciedlają one pewien zasób wiedzy i jej pojęciowej organizacji w obszarze stosunków prawnych, panujących u progu upadku Rzeczypospolitej szlacheckiej poprzez wzbogacenie relacji paradygmatycznych i rozbudowanie warstwy kognitywnej tekstu.

Drugą część omawianej książki otwiera artykuł o polszczyźnie doby stanisławowskiej w dzienniku Teofili z Jabłonowskich Sapieżyny. Na materiale rękopisu dziennika Sapieżyny I. Szczepankowska omawia zjawiska graficzne fragmentów tekstu spisanych w języku polskim oraz niektóre właściwości ortografii. Ponadto przedmiotem opisu czyni trudną w badaniu i opisie wymowę oraz odmianę wyrazów. W zakresie ortografii I. Szczepankowska obserwuje dużą zbieżność między analizowanym dziennikiem i osiemnastowiecznymi drukami. W omawianym rękopisie występują także zjawiska charakterystyczne dla XVI-XVII-wiecznej orografii oraz fakty graficzne pozostające pod wpływem ortografii francuskiej. Na czytelność i przejrzystość tekstu doskonale wpływa zamieszczona przez Autorkę tabela ilustrująca zwyczaje ortograficzne odzwierciedlone w dzienniku Sapieżyny. Materiał fonetyczny Autorka klasyfikuje według: a) cech zgodnych z osiemnastowieczną normą ogólnopolską, b) zjawisk, które zalicza do polszczyzny kresowej, c) właściwości powstałych pod wpływem dialektu mazowieckiego. Z badań I. Szczepankowskiej wynika, że w zakresie fleksji, podobnie jak w wypadku ortografii, rękopis Sapieżyny w niewielkim stopniu odbiega od zwyczajów panujących w XVIII w. Zaobserwowane przez Autorkę wahania w wyborze formy wyrazu wynikają $z$ utrzymy-

3 Wyniki tych badań zostały zawarte w monografii Język prazuny... 
wania się reliktowych końcówek staropolskich oraz mieszania się różnych wzorców deklinacyjnych i koniugacyjnych w odmianie niektórych wyrazów.

W kolejnym tekście I. Szczepankowska przedstawia składniowo-frazeologiczne wskaźniki tematu wypowiedzi, które różnią potoczną i literacką odmianę osiemnastowiecznej polszczyzny. Czyni to na materiale korespondencji (o charakterze bardziej literackim, składniowo uzależnionym od wzorca łacińsko-retorycznego) wojewody wileńskiego Karola Stanisława Radziwiłła oraz listów (korespondencji o charakterze bardziej potocznym, ujawniającym się w warstwie składniowo-stylistycznej i leksykalno-frazeologicznej) kasztelanowej kamieńskiej Katarzyny Kossakowskiej. Oba teksty prezentują różne sposoby wskazywania aktualnego tematu wypowiedzi, jak chociażby stosowanie konstrukcji nazywanej „nominativus pendens” licznie poświadczonej w listach Kossakowskiej.

Artykuł Z dziejów bilingwizmu polsko-francuskiego (na materiale dzienników i listów XVIII i 1. połowy XIX wieku) stanowi - jak sama Autorka stwierdza - przyczynek do szerszego opracowania zjawiska bilingwizmu polsko-francuskiego ujawniającego się w wiekach XVIII i XIX. W niniejszym opracowaniu I. Szczepankowska skupia swoją uwagę na bliższym zbadaniu mechanizmów przełączania kodu w wypowiedziach jednostek bilingwalnych oraz kalkowania konstrukcji języka francuskiego. Niebanalne spostrzeżenia i wnioski Autorka formułuje na podstawie materiału pochodzącego z rękopiśmiennego dziennika Sapieżyny i porównawczo z listów księżnej Franciszki Urszuli z Wiśniowieckich Radziwiłłowej z początku XVIII w. i dziennika Kamilli Bystrzonowskiej z I połowy XIX w. Wybór tekstów nie jest oczywiście przypadkowy. Wszystkie trzy panie znały francuski na podobnym poziomie, posługiwały się nim swobodnie w codziennych kontaktach, zapewne uczyły się go od dzieciństwa. I. Szczepankowska przyjmuje zatem, że dwujęzyczność autorek ma charakter „współrzędny”, wynikający z jednoczesnego opanowania obu kodów.

O językowych mechanizmach agitacji na rzecz „państwa prawa” w publicystyce polskiego oświecenia traktuje ostatnie studium omawianej książki. Warto podkreślić, że I. Szczepankowska nie tylko przedstawia tu zabiegi retoryczne takie, jak np. "dissociation de notion”, 
czyli „rozszczepienie pojęcia”, stosowane przez oświeceniowych publicystów, ale także odkrywa przed czytelnikiem istotę sztuki retorycznej oraz rozumienie jej przez współczesnych użytkowników języka. Ponadto Autorka pokazuje i udowadnia, że techniki klasycznej sztuki perswazji i retoryczne symbole są wciąż żywe, co zawdzięczają „z jednej strony temu, że są nośnikami uniwersalnych - przynajmniej w kulturze europejskiej - wartości, a z drugiej strony temu, że są wielowymiarowe i przez to podatne na swoistego rodzaju profilowanie, na odświeżającą konkretyzację" (s. 217).

Reasumując, należy stwierdzić, że niniejsza publikacja jest $\mathrm{z}$ pewnością pozycją wartościową. Autorka nie tylko przedstawia w niej interesujące zagadnienia stosując zróżnicowane metody opisu, ale też wytycza nowe problemy badawcze, które - miejmy nadzieję - będą dalej zgłębiane. 